\title{
Petrified auricle with ectopic ossification and trans- epidermal elimination of bone sequester: A case story and review of the literature
}

\author{
Benedicte Louise Hegelund Krogh ${ }^{1}$, Hanne Kjeldsen ${ }^{2}$, Lise Hanne Christensen ${ }^{3}$ \\ 1 Department of Pathology, Rigshospitalet, Copenhagen, Denmark. 2 Department of General Surgery, Sisiumut hospital, \\ Sisiumut, Greenland. 3 Department of Pathology, Herlev Hospital, Herlev, Denmark.
}

Correspondence: Lise Hanne Christensen. Address: Department of Pathology, Herlev Hospital, Herlev, Denmark. E-mail: lisec@dadlnet.dk

Received: October 7, 2014

Accepted: November 16, 2014 Online Published: December 9, 2014

DOI : $10.5430 /$ crcp.v2n2p17

URL: http://dx.doi.org/10.5430/crcp.v2n2p17

\begin{abstract}
Petrified auricle is a clinical condition in which parts of one or both auricles become rigid and stony hard due to calcification or ossification of cartilage. Auricular ossification is a rare clinical entity. Transepidermal elimination is an intricate epidermal and dermal tissue response to foreign material. Here we report a case of a 62-year-old Greenland man, who developed unilateral ectopic ossification of upper pole helix cartilage of the auricle in combination with trans epidermal elimination of a small bone sequester, causing inflammation and painful ulceration.
\end{abstract}

\section{Key words}

Petrified auricle, Transepidermal elimination

\section{I ntroduction}

Petrified auricle is a clinical or radiographic term for a condition, in which part of one or both ear helices are rigid and stony hard due to calcification or ossification of the cartilage ${ }^{[1-23]}$. Auricular ossification is a rare cause of petrified ear, and the diagnosis requires histological examination (see Table 1) in contrast to calcification (dystrophic, metastatic, iatrogenic or idiopathic), which is a more common cause of petrified ear (see Table 2).

Table 1. Previously published, histologically verified, cases of auricular ossification

\begin{tabular}{|c|c|c|c|c|}
\hline Ref & Author - year & Patient sex/age & Laterality & Etiology \\
\hline & Current case - 2013 & $\mathrm{M} / 62$ & $\mathrm{Rt}$ & Hypercholesterolemia \\
\hline 11 & Kim et al - 2011 & $\mathrm{M} / 53$ & $\mathrm{Lt}$ & Manipulation. Hearing loss \\
\hline 10 & Chang et al - 2011 & $\mathrm{~F} / 72$ & $\mathrm{Lt}$ & $\begin{array}{l}\text { Calcium intake for } 8 \text { years due to osteoporosis (+ } \\
\text { hypertension and diabetes) }\end{array}$ \\
\hline 9 & Mastronikolis et al - 2009 & $\mathrm{M} / 75$ & Rt \& Lt & Addisons disease+DM \\
\hline 12 & Carfrae - Foyt 2008 & $\mathrm{M} / 49$ & $\mathrm{Lt}$ & Idiopathic. Hearing loss \\
\hline 8 & Sterneberg-Vos et al - 2007 & $\mathrm{M} / 72$ & Right ear & Cold exposure - repeated \\
\hline 13 & Gonzales-Sixton et al 2006 & $\mathrm{M} / 80$ & Rt \& Lt & Cold exposure \\
\hline 14 & Manni et al - 2005 & $\mathrm{~F} / 63$ & Rt \& Lt & Idiopathic. Hearing loss \\
\hline
\end{tabular}


Table 1. (continued.)

\begin{tabular}{|c|c|c|c|c|}
\hline Ref & Author - year & Patient sex/age & Laterality & Etiology \\
\hline 15 & High et al - 2004 & $\mathrm{M} / 60$ & Rt \& Lt & Idiopathic \\
\hline 3 & Stites et al - 2003 & M/65 & Lt & Frost bite - repeated \\
\hline 4 & Yeatman \& Varigo - 1998 & $\mathrm{M} / 66$ & Rt \& Lt & Cold exposure \\
\hline 16 & Lautenschlager et al - 1994 & M/66 & Rt \& Lt & Cold exposure \\
\hline \multirow{2}{*}{17} & Cohen et al - 1991 & $\mathrm{M} / 46$ & Rt \& Lt & Addisons disease \\
\hline & Cohen et al - 1989 & $\mathrm{M} / 70$ & Rt \& Lt & Addisons disease.Hearing loss \\
\hline 2 & Lari et al - 1989 & $\mathrm{M} / 17$ & Rt \& Lt & Manipulation/trauma \\
\hline $17 \mathrm{a}$ & Cohen et al - 1989 & $\mathrm{M} / 70$ & Rt \& Lt & Addisons disease.Hearing loss \\
\hline 1 & DiBartolomeo - 1985 & $\begin{array}{l}\text { M/79 } \\
\text { M/85 }\end{array}$ & Rt \& Lt & Cold exposure \\
\hline 6 & Lister - 1969 & $\mathrm{M} / 58$ & Rt \& Lt & Idiopathic \\
\hline 20 & Gordon - 1964 & $\mathrm{~F} / 34$ & Rt \& Lt & Perichondritis \\
\hline 21 & Scherrer - 1932 & $\mathrm{~F} / 53$ & Rt \& Lt & Idiopathic \\
\hline 22 & Knapp - 1890 & $M / 24$ & Unilateral & Perichondritis. Multiple seromas \\
\hline 23 & Bochdalek - 1866 & $M / 65$ & & Idiopathic \\
\hline
\end{tabular}

Table 2. Diseases or conditions correlated with ossification of auricular cartilage ${ }^{[7,14,17]}$

\begin{tabular}{lll}
\hline Endocrine/Metabolic & Local tissue injury & Idiopathic \\
\hline Hyperparathyreodism & Repeated cold exposure \\
Diabetes mellitus & Frostbite \\
Addison's disease & Inflammation \\
Acromegaly & Chondritis \\
Adrenal insufficiency & Perichondritis \\
Hypopituitarism & Physical trauma/manipulation \\
Hyperthyroidism & \\
Ochronosis & \\
Hypercalcemia & \\
Systemic chondromalacia & \\
\hline
\end{tabular}

Trans-epidermal elimination (TE) is a process, by which a foreign body or a native constituent having undergone radical changes is eliminated from the skin surface ${ }^{[24,25]}$.

Here, we describe a case of a man, who, after having developed unilateral ectopic ossification of the upper pole helix cartilage of the auricle, developed a painful ulcer due to trans-epidermal elimination of a small bone sequester.

\section{Case report}

A 62-year-old male smoker from Greenland with known hypercholesterolemia, who underwent coronary bypass for atherosclerosis three years previously, was admitted with a large painful, non-healing ulceration on his right ear helix, which had lasted for months. An initial biopsy had shown inflammation suggesting folliculitis, but symptoms worsened, and the ulcer with an underlying broad rim of hard tissue was excised in toto. The tissue was decalcified and prepared for microscopic examination after paraffin embedment. Microscopically, the cartilage showed bone metaplasia in an area spanning approximately $2 \mathrm{~cm}$ with lamellar bone trabecula surrounding normal-looking marrow spaces (see Figure 1). The intervening connective tissue was characterised by an intense acute inflammatory response with necrosis and a more deeply seated chronic inflammation. Surrounded by hyperplastic epidermis, a small bone sequester was seen in the process of being transported towards the surface by trans-epidermal elimination (see Figure 2). 


\section{Discussion}

Ectopic ossification of the auricle is a rare cause of petrified ear and a phenomenon in which the normal elastic cartilage is transformed into lamellar bone ${ }^{[1,3,9,16]}$. Ectopic ossification appears either as part of rare syndromes characterized by abnormal de novo ossification (primary ossification) e.g. in Albright's hereditary osteo-dystrophy or as formation of lamellar bone in existing lesions (secondary ossification). The latter is more common and has been described in connection with cold exposure or frost bite, trauma, inflammation in and around some cutaneous neoplasms (e.g. pilomatrixoma, chondroid syringoma and nevi) ${ }^{[15]}$ (see Table 1 ) and in some systemic metabolic/endocrine diseases ${ }^{[3,6,9,14,17,20]}$, some of which are associated with hypercalcemia ${ }^{[19]}$ (see Tables 1, 2).

Figure 1. Overview of the histopathologic presentation of the case showing bone trabeculae instead of ear cartilage (arrows). The frame shows a bone sequester surrounded by chronic inflammatory cells (CII) making its way to the surface by trans-epidermal elimination. $\mathrm{H} \& \mathrm{E} \times 60$.

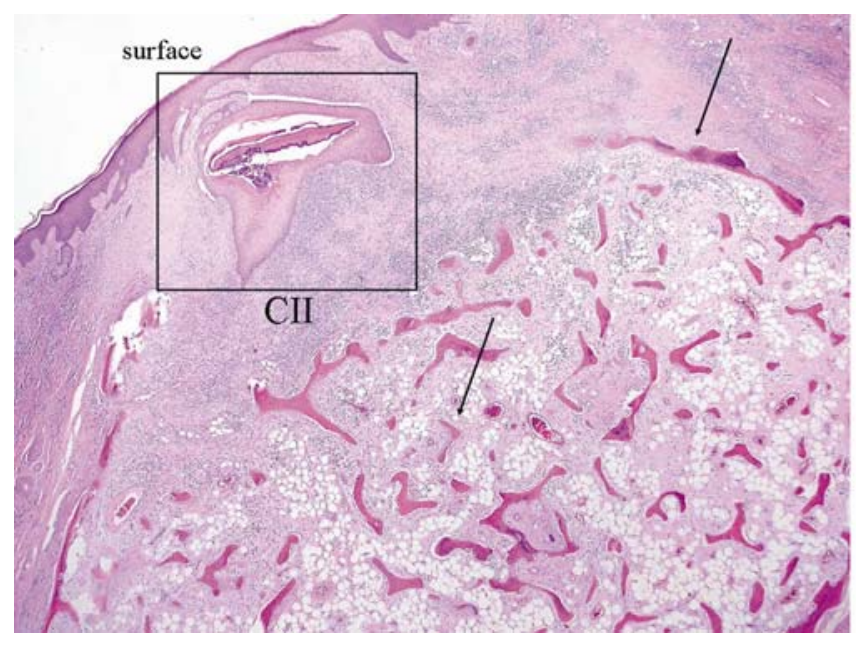

Figure 2. Close-up view of the bone sequester. Remnant Haversian canals are barely visible (arrows). H\&E $\times 200$.

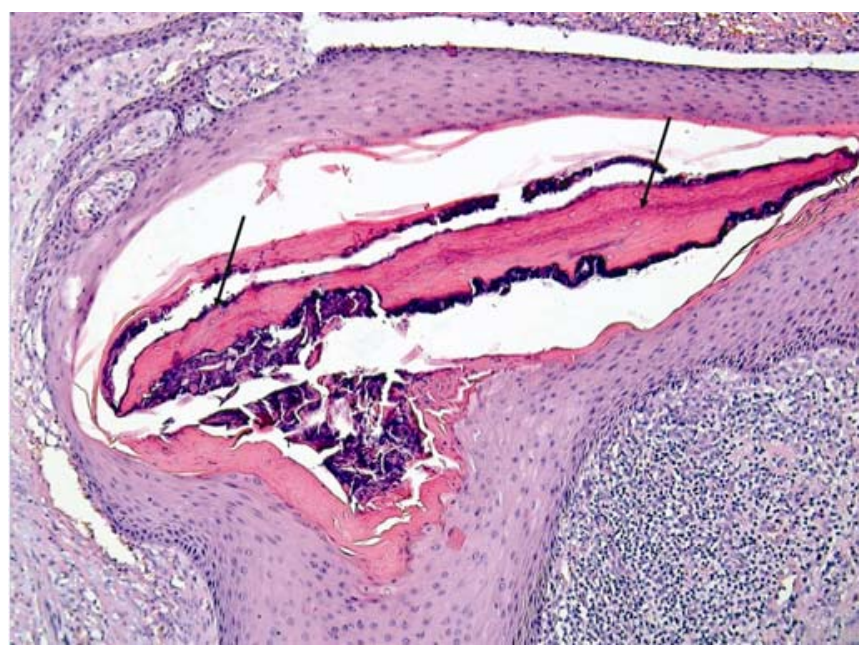

Petrified auricle with irreversible hardening of the elastic cartilage was first described in 1866 by Bochdalek et al. ${ }^{\text {[23] }}$, and $\mathrm{X}$-ray findings of this condition were described in $1899^{[1,19]}$. Since then, less than 200 cases have been published as case reports ${ }^{[3,10,18]}$. CT scans with minute radiolucent air spaces within bony opacities may indicate bone formation ${ }^{[10,19]}$, but to our knowledge only 22 published articles, including this case, have demonstrated histologically verified ectopic ossification (see Table 1). These numbers, however, may not necessarily reflect the real incidence. The condition is often asymptomatic or causes only mild discomfort, and few of the reported cases have been painful.

The majority of petrified auricles are caused by calcification without ossification. Tissue calcification includes: dystrophic calcification (deposition of calcium into damaged soft tissue in the presence of normal calcium metabolism), metastatic calcification (calcium deposition caused by hypercalcaemia), iatrogenical calcification (e.g. after calcium gluconate therapy ${ }^{[26]}$ or idiopathic calcification (unknown underlying cause). Ectopic tissue calcification, including ossification of Published by Sciedu Press 
the auricle, has been described in connection with systemic disorders such as diabetes mellitus and Addison disease (see Tables 1, 2) ${ }^{[9,10,17]}$. However, there is no evidence that calcification progresses to ossification, and ossified auricle should not necessarily prompt investigations for underlying conditions ${ }^{[4]}$, although laboratory/biochemical evaluation may be helpful in identifying particularly calcifying disorders.

The most commonly reported causes of auricular ossification are severe frostbite and recurrent exposure to cold (see Table 1). The pathogenesis mechanism that causes ectopic secondary ossification is unknown, but hypothetically hypothermia may lead to thrombosis, ischemia and proliferation of lamellar bone. Ossification may require a local event that initiates differentiation of mesenchymal cells into osteoprogenitor cells. The increased alkalinity of non-viable tissues may subsequently lead to deposition of calcium ${ }^{[3,10,15]}$.

Transepidermal elimination (TE) is an intricate epidermal and dermal tissue response to foreign material. The response is initiated by a pseudo-epitheliomatous epidermal hyperplasia which forms grooves to encase the foreign material. When wrapped inside proliferating epithelium the maturing keratinocytes will slowly transport the material upwards and eventually discard it. TE is best known for its ability to eliminate foreign bodies such as deep splinters or thorns, but it can also eliminate endogenous tissue, particularly if changed by e.g. inflammation, to make them behave like foreign bodies ${ }^{[24]}$. TE and chondrodermatitis nodularis helicis (CNH) are closely related lesions, characterized by a combination of chronic inflammation of unknown aetiology and an epidermal defect over the site, through which tissue components altered by the inflammation are extruded ${ }^{[18]}$. Unlike TE, CNH is relatively common and a painful auricle condition, thought to be triggered by mechanical injury after actinic (solar) damage or cold. Occasionally, bone formation may occur

in $\mathrm{CNH}$-nodules ${ }^{[4,18]}$, however only in small amounts in contrast to our case. To our knowledge only one published case has described CNH coexisting with petrified ear ${ }^{[4]}$.

This case adds to the small list of histologically verified cases of petrified ear. In contrast to many previous cases this case was painful and differed from the other cases by showing trans-epidermal elimination of a bone sequester.

\section{References}

[1] DiBartolomeo JR. The petrified auricle: comments on ossification, calcification and exostoses of the external ear. Laryngoscope. 1985; 95: 566-576. PMid: 3990487.

[2] Lari AA, Al-Rabah N, Dashti H. Acrobatic ears: a cause of petrified auricles. Br J Plast Surg. 1989; 42: 719-721. PMid: 2513998.

[3] Stites PC, Boyd AS, Zic J. Auricular ossificans (ectopic ossification of the auricle). J Am Acad Dermatol. 2003; 49: 142-4. Review. PMid: 12833029.

[4] Yeatman JM, Varigos GA. Auricular ossification. Australas J Dermatol. 1998; 39: 268-70. http://dx.doi.org/10.1111/j.1440-0960.1998.tb01489.x

[5] Aw J, Davies R, Cook J-L. Stone deaf: the petrified ear. Case report and review of the literature. Radiology Case Reports. 2011; 6: $1-4$.

[6] Lister GD. Ossification of the elastic cartilage of the ear. Brit J Surg. 1969; 56: 399-400. PMid: 4976415. http://dx.doi.org/10.1002/bjs.1800560522

[7] Clarke JT, Clarke LE, Miller JJ. Petrified ears: calcification of the auricular cartilage. J Am Acad Dermatol. 2004 ; 51: 799-800. PMid: 15523361.

[8] Sterneberg-Vos H, Winnepenninckx V, Frank J, Kelleners-Smeets MW. Ossification of the auricle. Int J Dermatol. 2007; 46 (Suppl 3): 42-4. PMid: 17973890.

[9] Mastronikolis NS, Zampakis P, Kalogeropoulou C, Stathas T, Siabi V, Geropoulou E, et al. Bilateral ossification of the auricles: an unusual entity and review of the literature. Head Face Med. 2009; 5: 17. PMid: 19796391. http://dx.doi.org/10.1186/1746-160X-5-17

[10] Chang K, Kim DK, Kim J, Park Y. Idiopathic acquired ectopic auricular ossification: a case report and review of the literature. Ear Nose Throat J. 2011; 90: 424-7. PMid: 21938701.

[11] Kim SY, Hong DK, Im M, Lee Y, Lee JH, Seo YJ. A case of Auricular Ossification. Ann Dermatol. 2011 ; 23 (Suppl 2): S261-3. PMid: 22148066. http://dx.doi.org/10.5021/ad.2011.23.S2.S2.S261 
[12] Carfrae MJ, Foyt D. Auricular ossification resulting in external auditory canal stenosis. Ear, nose, Throat J. 2008; 87: 148-9. PMid: 18404910.

[13] González-Sixton B, García-Doval I, Conde A, Mayo E, Pardavila R, de la Torre C, et al. Bilateral ossification of the auricular cartilage. Actas Dermosifiliogr. 2006; 97: 134-5. Spanish. PMid: 16595117.

[14] Manni JJ, Berénos-Riley LC. Ossification of the external ear: a case report and review of the literature. Eur Arch Otorhinolaryngol. 2005; 262: 961-4. PMid: 15965703.

[15] High WA, Larson MJ, Hoang MP. Idiopathic Bilateral Auricular Ossificans. Arch Pathol Lab Med. 2004; 128: 1432-4. PMid: 15578890.

[16] Lautenschlager S, Itin PH, Rufli T. The petrified ear. Dermatology. 1994; 189: 435-436. PMid: 7873840. http://dx.doi.org/10.1159/000246903

[17] Cohen A M, Talmi Y P, Floru S, Tsigelman R, Kalmanovic M, Zohar Y, et al. X-Ray Microanalysis of Ossified Auricles in Addison's Disease. Calcif Tissue Int. 1991; 48: 88-92. PMid: 1901512.

[18] Sehgal VN, Singh N. Chondrodermatitis nodularis. Am J Otolaryngology-Head and Neck Medicine and Surgery. 2009; 30: 331-36. PMid: 19720252.

[19] Buikema KE, Adams EG. A rare case of petrified ear. Case Rep Dermatol Med. 2012; ID41: 1-4. PMid: 23259082. http://dx.doi.org/10.1155/2012/410601

[20] Gordon D. Calcification of auricular cartilage. Arch Intern Med. 1964; 112:73-77.

[21] Scherrer F. Calcification and ossification of the external ears. Ann Otol. 1932; 41: 867-85.

[22] Knapp H. Ossification of the auricle in consequence of perichondritis seropurulenta. Arch Otol. 1890; $19: 45-50$.

[23] Bochdalek V. Verknocherung der Aurecula. Prag Vierteljahrschr. 1866; 89: 33-46.

[24] Woo TY, Rasmussen JE. Disorders of transepidermal elimination. Part 1. Int J Dermatol. 1985; 24: 267-79. PMid: 3160676.

[25] Woo TY, Rasmussen JE. Disorders of transepidermal elimination. Part 2. Int J Dermatol. 1985; 24: 337-48. Review. PMid: 3899955.

[26] Walsh JS, Fairley JA. Calcifying disorders of the skin. J Am Acad Dermatol. 1995; 33: 693-706; quiz 707-10. Review. PMid: 7593766. 